\title{
Analisis E-Learning Sebagai Media Bantuan Pengajaran di Lingkungan
}

\section{Kampus}

\author{
Rachmat Aulia \\ Jurusan Teknik Informatika Sekolah tinggi Teknik Harapan Medan \\ Jl. HM Joni No 70 A Medan 20152 Indonesia \\ Email : jackm4t@gmail.com ${ }^{1)}$
}

\begin{abstract}
Abstrak
Penerapan proses belajar mengajar dalam suatu kampus menggunakan metode konvensional semakin lama menyebabkan proses pembelajaran tidak efektif. Hal ini menimbulkan permasalah dalam lingkungan kampus bagaimana menciptakan suasana belajar yang interakatif sehingga tidak menimbulkan rasa bosan terhadap para mahasiswa. Konsep E-Learning merupakan teknologi yang dapat memberikan solusi untuk masalah pembelajaran. Penggunaan E-Learning dapat diakses dengan memanfaatkan teknologi internet melalui komputer. Metode yang dibahas dalam konsep E-Learning ini terdiri dari distance learning dan blended learning. Distance learning merupakan model pembelajaran jarak jauh yang mana jarak dan waktu tidak menjadi masalah dalam pengoperasiannya sedangkan blended learning merupakan model pembelajaran yang menggabungkan teknik belajar konvensional dengan pemanfaatan teknologi untuk pendistribusian pembelajaran seperti web.
\end{abstract}

kata kunci : analisis, E-learning, konvensional, bantuan pengajaran, jarak jauh

\section{Pendahuluan}

E-Learning merupakan suatu teknik metode pembelajaran yang bersifat konvensional yang ditransformasikan ke dalam bentuk digital menggunakan teknologi jaringan internet. Definisi lain E-Learning adalah penerapan teknologi internet yang dimanfaatkan sebagai sarana untuk pembelajaran. E-Learnig juga dapat diartikan sebagai proses pembelajaran yang menggunakan peralatan elektronik bertujuan untuk menginformasikan / menyampaikan informasi kepada para user (siswa/mahasiswa) untuk memudahkan proses belajar mengajar dengan menerapakan konsep interaktif tanpa pengaruh waktu.

Konsentrasi pengembangan sistem E-Learning ini tidak hanya menghadirkan materi ke dalam bentuk digital yang ter-upload di web server namun juga mengedepankan prinsip pembelajaran serta memikirkan efek atau respon yang berasal dari para user (siswa/mahasiswa) apakah rancangan yang telah di desain dapat membuat mereka tidak boring atau bosan dalam mengakses sistem E-Learning tersebut. [3]
Seiring pesatnya perkembangan teknologi dan semakin banyaknya data yang harus dikelola dalam suatu kampus untuk dapat menghasilkan informasi yang bermanfaat, penerapan E-Lerning ini merupakan solusi utama untuk memecahkan masalah pengelolaan data menjadi informasi yang berguna serta dapat diakses tanpa pengaruh waktu (anytime and anywhere). Banyak manfaat yang kita dapatkan dalam mengimplentasikan metode E-Leaning ini di kampus. Salah satu manfaat yang dapat dirasakan oleh mahasiswa adalah mereka bisa mendapatkan materi ajar yang telah diposting oleh para tenaga pengajar ke website kampus tanpa harus meng-copy setelah selesai setiap pertemuan perkuliahan. Mahasiswa juga dapat berinteraksi langsung dengan para dosen melalui aplikasi chatting yang telah dirancang dan merupakan fasilitas yang wajib ada dalam $E$ Learning. Selain aplikasi chatting terdapat juga sebuah forum. Forum dalam E-Learning dapat dijadikan ajang pertukaran pemikiran atau informasi antar sesama dosen dan mahasiswa sehingga dapat memberikan berbagai macam solusi yang kemungkinan tidak sempat terpecahkan pada saat pertemuan kuliah berlangsung atau solusi yang timbul dari para mahasiswa namun tidak berani mengemukakannya langsung dalam kelas.

Penerapan E-Learning dalam suatu kampus terkadang terhambat oleh infrastruktur dan kebutuhan yang harus disesuaikan dengan permasalahan yang timbul di kampus. Kita pasti paham bahwasanya untuk membangun $E$ Learning dalam kampus harus membangun dulu jaringan komputer yang dapat mensinkronisasikan keseluruhan bagian-bagian dalam kampus seperti: biro akademik, fakultas, program studi, perpustakaan, keuangan serta bidang lain-lain yang belum disebutkan. Setelah teknologi jaringan terinstal dan dapat bekerja dengan benar, barulah E-Learning tersebut dapat dikembangkan. Untuk mengembangkan sistem E-Learning diharapkan pihak kampus telah mempunyai sebuah server yang dapat mengelola data yang akan di-input dalam E-Learning tersebut. [7] 


\section{Metodologi E-learning}

Metodologi adalah teknik atau model yang diterapakan dalam suatu sistem agar dapat mendeskripsikan proses-prosesnya secara sistematis dan terarah. Metode penerapan $E$ Learing harus disesuaikan dengan kebutuhan yang ada di lapangan. Berbagai macam metode pembelajaran elektronik antara lain seperti berikut:

\section{Distance learning}

Metode pembelajaran E-Learning ini merupakan proses belajar mengajar yang tidak memandang jarak dan waktu sebagai kendala. Saat ini banyak orang menginginkan belajar di kampus - kampus ternama. Terkadang mereka dihadapkan oleh tantangantantangan lain seperti: jarak kampus yang terlalu jauh (tinggal di sumatera, letak kampus di pulau jawa) dan sudah bekerja di luar daerah, (dapat kerja di Medan tapi ingin kuliah di Jawa atau luar negeri seperti Malaysia). Metode ini hadir untuk memberikan kemudahan akses dalam pembelajaran jarak jauh. Konsentrasi yang dihasilkan dari metode ini adalah penerapan teknologi dan mendesain sistem E-Learning untuk melakukan proses pembelajaran kepada mahasiswa tidak secara fisik melainkan interaktif [3]. Penerapan teknologi dengan membangun sistem $E$ Learning memungkinkan antara dosen dan mahasiswa dapat bertukar pikir secara real time yang terhubung langsung ke jaringannya (online). Implementasi yang dihadirkan dalam metode distance learning terdiri dari dua jenis yaitu: synchronous dan asynchronous. Pada umumnya metode ini diterapkan dalam beberapa kampus atau sekolah, seperti mendesain interface yang digunakan untuk media pembelajaran jarak jauh dengan menerapkan konsep interaktif untuk menyajikan materi-materi yang akan dipelajari, membuat video tutorial yang berhubungan dengan materi yang akan dipresentasikan, membuat interface quiz pembelajaran untuk mengukur seberapa dalam pemahaman terhadap materi yang telah diberikan sebelumnya, merancang interface yang berhubungan dengan penilaian mahasiswa yang dapat mereka akses secara online, desain form untuk mengirimkan tugas yang diberikan oleh tenaga pengajar dan pengajar dapat mengakses ke akun masingmasing untuk dapat mendownload tugas-tugas dari para mahasiswanya, fasilitas chatroom yang ditunjang dengan konsep real audio dan video atau bisa dikatakan sebagai online meeting, penerapan mailing list atau forum untuk berdiskusi dalam mencari solusi dari suatu permasalahan yang timbul behubungan dengan pembelajaran.

Hal yang paling penting dalam metode distance learning ini adalah permasalahan yang berhubungan dengan tidak ditemukannya interaksi antara mahasiswa dengan para tenaga pengajar. [7]

\section{Blanded Learning}

Blended learning merupakan metode pembelajaran yang menggabungkan teknik konvensional dengan pembelajaran secara $E$ Learning menggunakan website (online). Defini metode blended learning ini sebenarnya dapat kita kajian dari dua kata yaitu: Blended dan Learning. Blended berarti mencampurkan atau gabungan, sedangkan Learning adalah belajar. Apabila kedua kata tersebut kita gabungkan maka menghasilkan makna penggabungan teknik pembelajaran. Unsur yang digabungkan dalam metode ini adalah bagaimana melakukan pembelajaran di kelas (classroom lesson) dengan pembelajaran di luar kelas yaitu online learning.

Berikut ini adalah beberapa definisi yang berhubungan dengan blended learning: [7]

1) Kombinasi yang menggabungkan teknik pembelajaran tradisional dengan pemanfaatan dokumen elektronik menggunakan teknologi web dalam penyajiannya

2) Metode pembelajaran yang menggabungkan beberapa aspek seperti: penggunaan teknologi web, penerapan streaming video, komunikasi audio baik secara sinkronisasi maupun asinkronisasi

3) Pengganbungan model belajar mengajar dengan cara mencampurkan antara teknik pembelajaran tradisional (face-to-face) dalam kelas dengan model pembelajaran yang terdistribusi dari pusat (server) yang keseluruhan data dikumpulkan dari para tenaga pengajar unutk diberikan ke mahasiswa (client) sebagai end user-nya.

Berdasarkan definisi di atas maka dapat disimpulkan bahwa metode blended learning lebih menekankan kepada penggabungan / penyatuan metode pembelajaran secara konvensional (face-to-face) dengan metode $e$ learning. Seperti terlihat pada Gambar 1 dibawah ini : 


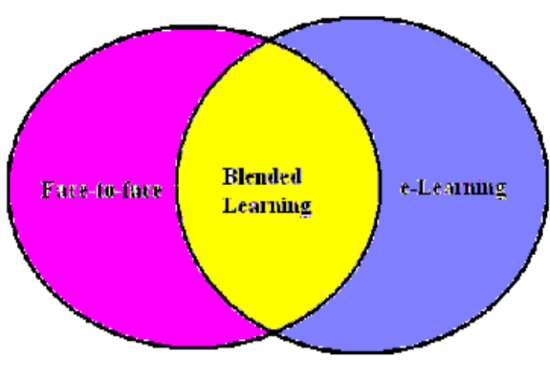

Gambar 1: Posisi Irisan Blanded Learning [1] [7]

Dalam penerapannya blanded learning menggabungkan berbagai sumber secara fisik dan maya (virtual) dengan pendekatan seperti disajikan pada Tabel 1 berikut:

Tabel 1.Blanded Learning

\begin{tabular}{|c|c|}
\hline $\begin{array}{l}\text { Live face-to-face } \\
\text { (formal) }\end{array}$ & $\begin{array}{l}\text { Live face-to-face } \\
\text { (informal) }\end{array}$ \\
\hline $\begin{array}{l}\text { Instructor-led } \\
\text { classroom } \\
\text { Workshops } \\
\text { - Coaching/monitor } \\
\text { ing } \\
\text { On-the-job (OTJ) } \\
\text { training }\end{array}$ & $\begin{array}{l}\text { - Collegial } \\
\text { connections } \\
\text { - Work teams } \\
\text { - Role modeling }\end{array}$ \\
\hline $\begin{array}{l}\text { Virtual } \\
\text { Collaboration / } \\
\text { synchronous }\end{array}$ & $\begin{array}{l}\text { Virtual } \\
\text { collaboration/ } \\
\text { asynchronous }\end{array}$ \\
\hline $\begin{array}{l}\text { Live e-Learning } \\
\text { classes } \\
\text { - E-mentoring }\end{array}$ & $\begin{array}{l}\text { - E-mail } \\
\text { - Online bulletin } \\
\text { boards } \\
\text { - Listservs } \\
\text { - Online } \\
\text { communities }\end{array}$ \\
\hline Self-paced learning & Performance support \\
\hline $\begin{array}{l}\text { Web learning } \\
\text { modules } \\
\text { - Online resource } \\
\text { links } \\
\text { - Simulations } \\
\text { - Scenarios } \\
\text { Video and audio } \\
\text { CD/DVDs } \\
\text { - Online self- } \\
\text { assessments } \\
\text { Workbooks }\end{array}$ & $\begin{array}{ll}\text { - } & \text { Help systems } \\
\text { - } & \text { Print job aids } \\
\text { - } & \text { Knowledge } \\
\text { databases } \\
\text { - } \\
\text { - } \\
\text { Pecumentation } \\
\text { ion support tools }\end{array}$ \\
\hline
\end{tabular}

Sumber: [Strategies for building blended learning By Allison Rosset, Felicia Douglis, and Rebecca V. Frazee]

\section{Analisis Pembahasan}

Berdasarkan variable dari konsep e-learning yang dianalisis adalah penyediaan kelas-kelas baru setara dengan kelas konvensional di lembaga pendidikan. Oleh karena itu, pembangunan sebuah lembaga pendidikan virtual seperti $e$ learning ini haruslah memberikan hasil yang kurang lebih sama dengan cita-cita untuk mendirikan sebuah lembaga pendidikan konvensional. Intinya, sistem e-learning ini diadaptasikan dari sistem yang ada di lembaga pendidikan konvensional ke dalam sebuah sistem digital melalui Internet. Sebagai sebuah hasil pencangkokan dari benih sistem pendidikan induk yang sama, juga mewarisi sifat-sifat dan sistem yang dilakukan oleh induknya. Salah satu contoh yang paling nyata adalah proses belajar-mengajar. Seorang pengajar akan memberikan materinya kepada para siswa yang ada di berbagai tempat dengan dihubungkan oleh Internet. Metode ini kurang lebih sama dengan proses belajarmengajar yang ada di sekolah konvensional. Dari sifat tersebut, jelaslah bahwa pengembangan teknologi e-learning harus didasarkan pada sifat dan karakter asli dari sistem pendidikan yang telah ada [8].

Dari sisi teknologi, sistem yang paling disukai adalah sistem yang sederhana, menarik, dan mudah untuk digunakan. Dalam hal ini, perencanaan sistem e-learning yang baik haruslah dapat menarik pengguna dengan menampilkan desain antarmuka yang interaktif, sehingga membantu pengguna untuk betah berada dalam kelas virtual tersebut. Berikut ini adalah context diagram dari sistem e-learning.

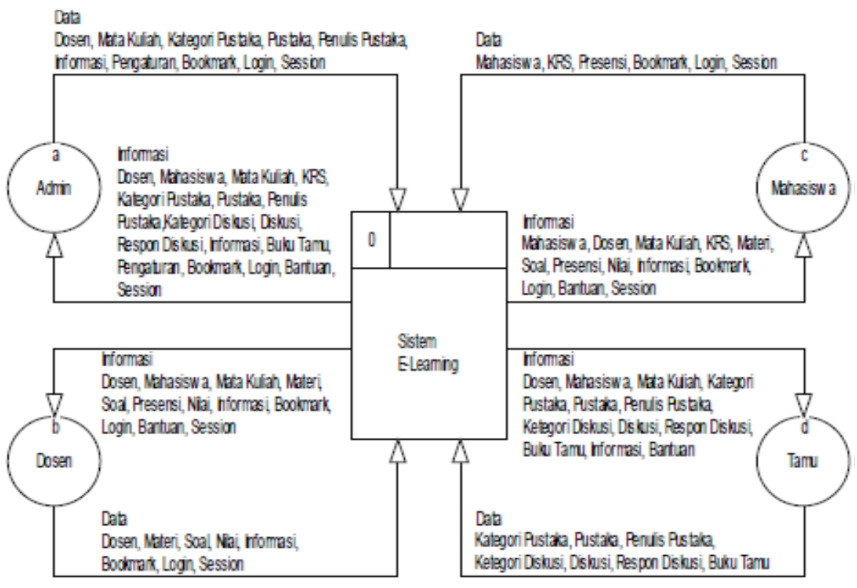

Gambar 2: Context Diagram Sistem E-

\section{Learning [2]}

Di dalam proses ini yang terjadi antara lain: login dosen, mahasiswa,admin dan pertukaran informasi mengenai modul, materi, dan evaluasi dari kuliah yang diberikan. Kemudian analisis isi yang meliputi analisis untuk mengetahui deskripsi matakuliah secara online bagi siapa saja yang telah mengakses sistem elearning, fasilitas upload modul dan evaluasi perkuliahan bagi dosen serta fasilitas download bagi mahasiswa yang telah mendaftarkan diri ke dalam sistem ini dan laporan statistik kepada pengelola situs mengenai pemanfaatan situs, fasilitas forum tukar informasi dan artikel mengenai proses 
perkuliahan, fasilitas untuk mendapatkan hubungan/link dengan sistem informasi akademik lainnya yang terintegrasi dengan web. Tahapan selanjutnya adalah analisis interaksi (Interaction Analysis) yaitu analisis tentang pemakai yang akan berinteraksi dengan aplikasi web dengan cara login dan terjadi otentikasi, dimana username dan password yang sesuai dengan sistem basis data yang dapat masuk ke aplikasi. Pelajar dapat secara langsung menggunakan semua fasilitas-faslitas yang diberikan oleh sistem setelah proses login berhasil. Setelah hal tersebut selesai proses selanjutnya adalah analisis fungsi (functional analysis) yang akan membahas fungsi-fungsi yang ada pada aplikasi web yang akan dibuat antara lain: administrasi user oleh admin, upload dan download materi kuliah dan evaluasinya, forum tukar informasi antara dosen dan mahasiswa, Layanan berupa mail system kepada pengguna situs, memberikan laporan perkembangan Desain dari sistem yang dibuat juga dapat diwakili dengan ERD (Entity Realitionship Diagram) berikut merupakan desain dari ERD

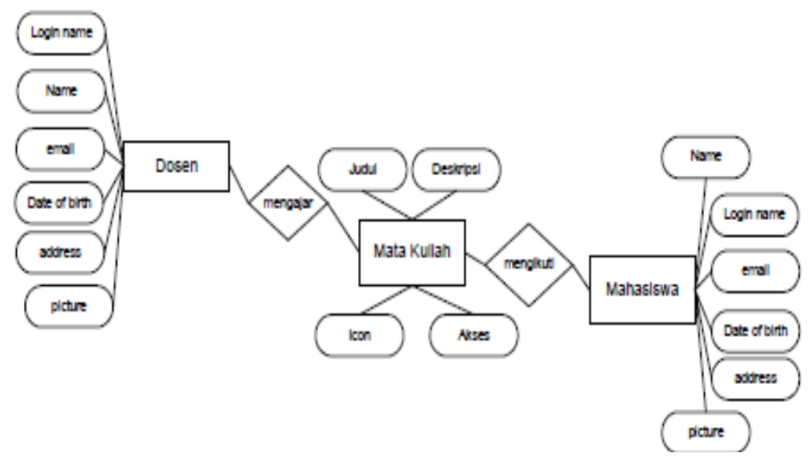

Gambar 3: ERD E-Learning [4]

\section{Hasil Analisis}

Berdasarkan analisis yang penulis telah jabarkan seperti di atas maka dapat disimpulkan penggunaan konsep e-learning memang sangat bearti dalam membantu kegiatan belajar mengajar di lingkungan kampus atau perguruan tinggi. Ketika sebuah kampus berniat melakukan perancangan sebuah tools dalam menunjang kegiatan belajar mengajar yaitu e-learning maka secara tidak langsung baik mahasiswa maupun kampus akan mendapatkan nilai tambah yang berarti kualitas pelajar atau kampusnya akan menjadi lebih baik. Hal ini kita dapat buktikan bahwasannya metode pengajaran yang umum dilakukan kebanyakan kampus atau perguruan tinggi adalah pengajara di dalam kelas (face-toface) yang seperti kita ketahui jarang mahasiswa atau pelajar mengerti dalam arti paham dan menguasai penuh materi yang diberikan oleh pengajar. Kebanyakan dari mereka apabila setelah selesai melakukan kegiatan belajar-mengajar di dalam kelas maka apa yang telah diajarkan sebelumnya mereka tidak kuasai atau bahkan tidak tahu alias lupa apa yang telah diberikan oleh dosen. Melalui penelitian ini penulis menghadirkan solusi dari permasalahan nyata yang umumnya terjadi dalam kegiatan belajar mengajar menggunakan metode tatap muka (meeting in classroom) di lingkungan kampus atau perguruan tinggi.

Metode yang dibahas pada penelitian ini adalah distance learning dan blanded learning. Kedua metode ini penulis gunakan karena menggabungkan sistem pengajaran jarak jauh dengan sitem pengajaran konvensional di lingkungan kampus atau perguruan tinggi. Pengajaran di luar kampus dapat diimplementasikan dengan merancang suatu sistem berbasis web dimana para pelajar atau mahasiswa dapat mengakses sistem e-learning memakai media internet. Pada umumnya layanan yang harus disediakan dalam membangun sebuah sistem e-learning dapat digambarkan ke dalam use case diagram seperti yang tampak di bawah ini:

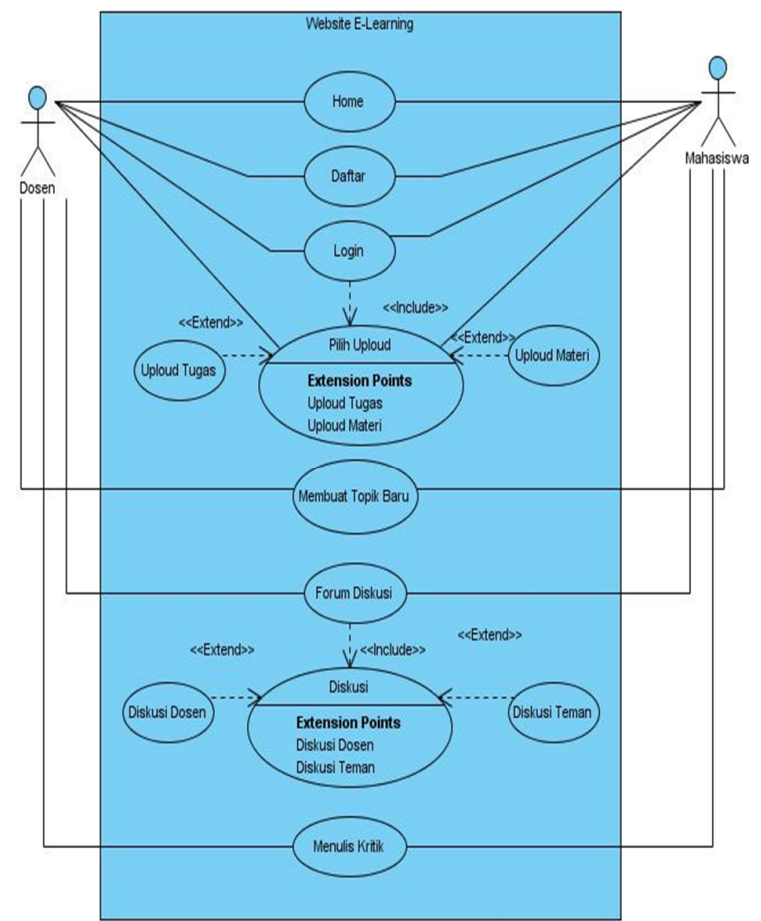

Gambar 4: Ilustrasi Proses E-Learning Menggunakan Use Case Diagram [5]

Penjelasan dari ilustrasi use case diagram di atas merupakan contoh sistem e-learning yang pada umumnya dapat diterapkan di lingkungan kampus 
atau perguruan tinggi. Hal lain yang dapat dijelaskan adalah perbedaan antara sistem belajar konvensional dengan sistem belajar digital $(e$ learning). Perbedaan tersebut dapat dilihat seperti Tabel 2 berikut:

Tabel 2. Perbedaan Metode Pembelajaran Konvensional dengan E-Learning [6]

\begin{tabular}{|c|c|}
\hline Pembelajaran Tatap Muka & Pembelajaran dengan e-Learning \\
\hline $\begin{array}{l}\text { Pembelajaran dilakukan secara tatap muka } \\
\text { Interaksi antara dosen dan mahasiswa dilakukan secara } \\
\text { tatap muka }\end{array}$ & $\begin{array}{l}\text { Menggunakan sistem belajar jarak jauh } \\
\text { Interaksi antara dosen dan mahasiswa dilakukan melalui } \\
\text { media dalam konsep maya }\end{array}$ \\
\hline Peran dosen sangat dominan & Terfokus pada mahasiswa \\
\hline Kemajuan belajar tergantung pada dosen & $\begin{array}{l}\text { Mahasiswa sangat berperan dalam } \\
\text { kemajuank keberhasilan belajarnya }\end{array}$ \\
\hline $\begin{array}{l}\text { Dosen dan mahasiswa harus bertemu pada saat waktu } \\
\text { yang sama }\end{array}$ & $\begin{array}{l}\text { Dosen dan mahasiswa tidak harus bertemu pada } \\
\text { saatwaktu yang sama }\end{array}$ \\
\hline Dosen sangat berperan dalam proses belajar mahasiswa & Menerapkan konsep belajar mandiri \\
\hline $\begin{array}{l}\text { Karena tatap muka, maka kedua belah pihak harus } \\
\text { memiliki kemampuan berkomunikasi dalam konteks tatap } \\
\text { muka }\end{array}$ & $\begin{array}{l}\text { Dibutuhkan kemampuan berkomunikasi dengan bahasa } \\
\text { tulis }\end{array}$ \\
\hline $\begin{array}{l}\text { Bagi dosen, khususnya, harus memiliki kemampuan } \\
\text { berbicara di depan kelas }\end{array}$ & $\begin{array}{l}\text { Kedua belah pihak dituntut untuk memiliki kemampuan } \\
\text { dalam menggunakan media/ komputer dan jaringan } \\
\text { komputer (internet) }\end{array}$ \\
\hline
\end{tabular}

Dapat disimpulkan dari tabel di atas, bahwasanya pembelajaran dengan metode digital jauh lebih efektif dan membuat para pelajar / mahsiswa lebih mandiri dalam menguasai materi dan mencari solusi dari permasalahan yang diberikan oleh pengajar.

\section{Kesimpulan}

Sistem E-Learning merupakan aplikasi yang diharapkan mampu mendukung proses kegiatan belajar-mengajar. Sehingga melalui e-learning, proses belajar mengajar dapat dilakukan dengan cepat dan mudah serta dapat meningkatkan efisiensi dan efektifitas waktu dan biaya.Elearning yang sekarang mampu mengatasi masalah pendidikan dan membuka cakrawala baru dalam proses belajar mengajar sehingga menjadi alternatif yang harus diterapkan dalam rangka pemahaman suatu materi pelajaran. Kendala yang masih dirasakan adalah permasalahan kesiapan sumber daya manusia (SDM) baik dari sisi pengajar maupun mahasiswa. E-learning juga memiliki keterbatasan diantaranya menuntut budaya self-learning yang mana seseorang memotivasi diri sendiri agar mau belajar dan tidak bergantug pada pengajar. Kendala yang masih dirasakan adalah permasalahan kesiapan sumber dayamanusia (SDM) baik dari sisi pengajar maupun mahasiswa.

\section{References}

[1] Al-Hunaiyyan, A., Al-Huwail, N. \& AlSharhan, S. 2008, Blended E-Learning Design: Disccussion of Cultural Issues,
International Journal of Cyber Society and Education, Vol. 1, No. 1, 17-32.

[2] Susanti, E. \& Sholeh, M. 2008, Rancang Bangun Aplikasi E-Learning, Jurnal Teknologi, Vol. 1, No. 1, 53-57

[3] Hadiyanti, N. 2010, Sistem E-Learning Untuk Meningkatkan Proses Belajar Mengajar: Studi Kasus Pada SMA Negeri 10 Bandar Lampung, Jurnal Telematika MKOM, Vol. 2, No. 2

[4] Haditian, J., Kristalina, P. \& Assidiqi, H. M. 2006, Pembuatan Sistem E-Learning Berbasis Content Management System, Kampus ITS, Surabaya.

[5] Maimunah \& Andrian, R. 2011, Rancang Bangun Aplikasi Media E-Learning Artificial Informatics Berbasis Web, Jurnal Digital, Vol. 1, No. 2

[6] Darmayanti, T., Setiani, Y. M. \& Oetojo, B. 2007, E-Learning Pada Pendidikan Jarak Jauh: Konsep Yang Mengubah Metode Pembelajaran Di Perguruan Tinggi Di Indonesia, Jurnal Pendidikan Terbuka dan Jarak Jauh, Vol. 8, No. 2, 99-113

[7] Wijaya, M. 2012, Pengembangan Model Pembelajaran e-Learning Berbasis Web dengan Prinsip e-Pedagogy dalam Meningkatkan Hasil Belajar, Jurnal Pendidikan Penabur, Vol. 11, No. 19

[8] Yazdi, M. 2012, E-Learning Sebagai Media Pembelajaran Interaktif Berbasis Teknologi Informasi, Jurnal Ilmiah Foristek, Vol. 2, No. 1 